\title{
Sokaktaki Müzik: Kapı Önünde Mayalanan Bir Halk Gösterisi
}

\author{
Bülent Kabaş \\ Dr. Öğr. Üyesi \\ Sakarya Üniversitesi \\ Sanat Tasarım ve Mimarlık Fakültesi \\ Orcid:0000-0002-7623-9275
}

\section{Öz}

Sokak sanatı kamusal mekânlarda gönüllü olarak gerçekleştirilen performansları tanımlayan bir terimdir. Günümüzde tüm dünyada yaygın bir biçimde icra edilen bir iş olan sokak sanatçılı̆̆ı ise oyunculuk, şarkıcılık, ressamlık, şairlik, müzisyenlik, hokkabazlık gibi çok çeşitli yeteneğin sergilenmesine dayalıdır. Kamusal alanda en görünür biçimi sokak müzisyenliği olan bu performans sanatlarına bugün özellikle sokaklar, meydanlar, metro istasyonları gibi çeşitli kent mekânlarında sıkça rastlamak mümkündür. Sokak müziği, geçtiğimiz on yıllar boyunca sosyoloji, hukuk, medya ve kültürel çalışmalar, kentsel tasarım, turizm, toplumsal tarih gibi birçok disiplin içinde akademik ilgiyle karşılanmış bir konu olmuştur. Bu çalışmada, sokak müziği pratiklerinde zaman içinde yaşanan dönüşümler gündelik hayat, kamusal alan ve kent mekânları ile ilişkisi bağlamında ve toplumsal değişimler ekseninde incelenmektedir. Bu bağlamda, tarih boyunca çok çeşitli toplumsal, siyasal ve kültürel işlevlerle donatılmış olan sokak müziğinin özellikle 60'lı yıllarla birlikte kültürel ve yaratıcı endüstriler tarafından keşfedilmesi ile başlayan süreçte, gösteri toplumunun bünyesine geçirdiği bir tüketim ve eğlence ortamına dönüşmesi irdelenmektedir.

Anahtar Kelimeler: Sokak müziği, sokak sanatı, troubadour, busking 


\section{Music on the Street: A Folk Spectacle in front of the Door}

\section{Abstract}

Street art is a term used to define the voluntary performances that take place within the public sphere. This kind of art, which takes place globally mainly, consists of acting, singing, painting, poetry, music and juggling. Street music, most widely witnessed kind of street art is to be found on streets, squares and subway stations of big cities. For the past decades, street music has been a focus of interest in various academic disciplines such as sociology, law, media, cultural studies, urban design, tourism and social history. Throughout this article, changes in the performing practices of street music are analyzed by keeping perspective of daily life, public sphere, urban structures and social changes. In this context, a transformation of street music endowed by various social, political and cultural functions that are discovered by the creative industry especially during the 60s, before turning into an entertainment and consumption space is the center of discussion.

Key Words: Street music, Street art, troubadour, busking

\section{Musique dans la Rue: Un Spectacle de Folk devant la Port}

\section{Resumé}

L'art urbain est un terme qui décrit les performances effectuées volontairement dans des espaces publics. Aujourd'hui, l'art urbain, qui est largement pratiqué dans le monde entier, comprend exposition d'un large éventail de talents tels que le théâtre, le chant, la peinture, la poésie, la musicalité, la jonglerie. Les musiciens de rue qui sont visible dans l'espace public sont fréquemment rencontrés en particulier dans divers lieux urbains tels que les rues, les places et les stations de métro. Dans les dernières dix années, la musique de rue a fait l'objet d'un intérêt académique dans de nombreuses disciplines telles que la sociologie, le droit, les sciences des médias et de la culture, le design urbain, le tourisme et I'histoire sociale. Dans cette étude, les transformations vécues au fil du temps dans les pratiques de la musique de rue sont examinées dans le contexte de la vie quotidienne, de l'espace public et des relations avec les espaces urbains et dans le contexte des mutations sociales. Dans ce contexte, la musique de rue, qui a été dotée de nombreuses fonctions sociales, politiques et culturelles tout au long de son histoire, qui a commencé avec la découverte des industries culturelles et créatives dans les années 60, la transformation de la société du spectacle en un environnement de consommation et de divertissement a été examinée.

Les Mots-cles: Le musique de Rue, art urbain, troubadour, busking

\section{Giriş}

Sokak müziğinin kalitesi ve sanatsal içeriği tartışılmasına rağmen tüm dünyada hızla gelișmeye devam etmektedir. Sokak müzisyenliği ise, modern bir şehir uğraşı ve ifade biçimidir. Sokakta, herkesin görmesini istemekten başka hiçbir şey beklenmeden yapılan bu sanat, izleyici ile üreticiyi aracısız bir şekilde bir araya getiren özel bir gösteridir.

Tiyatro ve konser salonlarının mekânsal özellikleri (akustiği, ışıklandırımış sahnesi ve bu sahnedeki gösteriyi en iyi görecek şekilde konumlandırımış koltuklarıyla) sokaktan çok daha farklı bir tasarıma sahiptir. Bu anlamda kapalı salonlar performansı destekleyici bir ortam sağlar; teatral illüzyona izin verir, ayrıca daha büyük incelik ve duygusal derinliği mümkün kılan bir odak üretirler. Oysa ki, sokak bu bağlamda bildiğimiz anlamdaki konvansiyonel gösterilere uygun bir mekân değildir. Sahnesi sokak olan sanatçının başarısı kentsel mekânı tüm zorluklarına rağmen (sokaktaki gürültüler, sabırsız izleyici, hava şartları, güvenlik tehditleri, vb.) bir gösteri alanına / mecraya dönüştürebilmesiyle doğru orantılıdır (Harrison-Pepper, 1990,140). Bunun için eylemlerinin çoğunu şehrin ve ortamın genel ritmine göre farklılık oluşturacak şekilde belirleyen sokak sanatçısının izleyicisiyle kurduğu yakın temas ve etkileşim onun lehine olabilmektedir. Dış mekânda değişen koşullar ve kesintiler, her bir performansın benzersiz bir olay olduğu anlamına gelir. lç ortam performansları ise daha kolay bir șekilde tekrarlanabilir olma eğilimindedir. Fakat bu tekrara dayalı performanslarda esnekliğin olmayışı sunumu mekanikleştiren bir unsundur (Mason, 1992, ss.86-87). Bu bağlamda, açık havada gerçekleștirilen performans, izleyiciler üzerinde daha büyük bir etkiye sahip olabilir; farklı insanları bir araya getirir, onları kuşatabilir, düşsel yolculuklara çıkarabilir, beklenmedik yerlerde ortaya çıkarak izleyenleri şaşırtabilir, hatta onları gösterinin seyreyleyeni olmanın ötesine taşıyarak katılımcı aktörlere de dönüştürebilir. Olasılıkların genişlemesi sokak sanatçılarına duyulan ilgiyi artıırmaktadır. Sokak sanatının, sınırların yıkılması ve insanlar arasındaki mesafelerin aşılması noktasında bir eşitleyici gücü olduğu da düşünülmektedir. Fatih Akın'ın İstanbul Hatırası (Crossing The Bridges) belgeselinde sokak müziği yapan Siya Siyabend adlı grubun üyelerinden Dede Murat'ın söylediği sözler bu anlamda dikkat çekicidir: "Sokak hemzemin oluşundan dolayı insanları birleştirir. Hangi sınıfsal temelden olursan ol, bütün insanları aynı hizaya getirebilir; böyle bir özelliği vardır sokağın..."

Bu çalışmada, sokak sanatlarının tarihsel serüveni içinde sokak müziğinin özgün yeri irdelenmekte ve geleneksel gösteri formları karşısındaki konumu ele alınmaktadır. Sokak müziği pratiklerinde zaman içinde yaşanan dönüşümlerin izini sürerken, gösterinin gündelik hayat, kamusal alan ve kent mekânları ile ilişkisini denkleme yerleştirmek ve toplumsal değişimler ile bağını sorgulamaksa kaçınımazdır. Bu bağlamda, tarih boyunca çok çeşitli toplumsal, siyasal ve kültürel işlevlerle donatılmış olan sokak müziğinin özellikle 60'lı yıllarla birlikte kültürel ve yaratıcı endüstriler tarafından keşfedilmesi ile başlayan süreçte, gösteri toplumunun bünyesine geçirdiği bir tüketim ve eğlence ortamına dönüșmesiyle tamamlanan bir zaman mekânsal döngünün serimleyici analizine girişilmektedir. 


\section{Tarihin Çemberinde Sokak Müziği: ‘Troubadour'dan ‘Busker’a}

İlk sokak performansının nerede ve nasıl gerçekleştiğini bilebilmek imkânsız olsa da, sokak sanatının kökeni birçok kaynakta Xl. yüzyılda orta Fransa'da rastlanan 'troubadour' adı verilen şövalye-saz şairleri ve gezgin şarkıcılara dayandırımaktadır. Çoğu erkek olan erken dönem 'troubadour'lar şair ve besteci asillerdir ve çoğu icracı değildir. Bilindiği kadarıyla 'troubadour'lar 'minstrel' adı verilen müzisyenlerle birlikte gösteri yaparlardı. O dönemden günümüze çoğu soylu kadına duyulan aşkı konu edinen 4000'e yakın şiir ve 1600 civarında melodi ulaşmıştır (Hoffer, 2012, s. 64). Ezgi ve şiir yaratıcısı olan 'troubadour'ların performansları söze ve müziğe dayalıdır; bu bağlamda sözlü kültür aktarıcısı konumundaki âşıklar ve ozanlarla da benzerlik göstermektedirler.

Figür 1: Ortaçağ'da Fransa'da ortaya çıkan troubadour'ların tasviri

(Kaynak: http://www.medievalists.net/2012/02/troubadours-and-their-heritage-in-the-edges-of-europe-singing-and-rapping-experiences-of-being-in-a-minority-in-southern-france-and-in-samiland/) (Erişim Tarihi 15/4/2019)

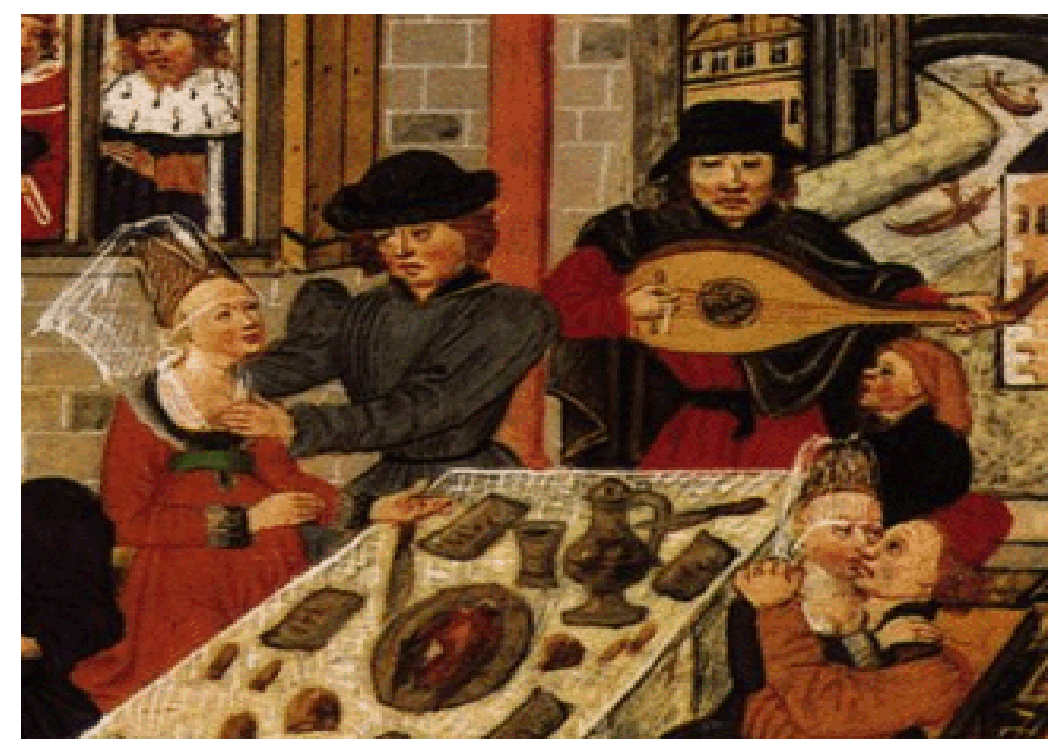

XI. yüzyılla XIII. yüzyıl arasında Avrupa derebeylerinin şatolarında, kalelerinde şarkı söyleyen 'troubadour'lar yavaş yavaş kilise baskısından kurtularak, dünyasal konulu ve yaşama sevinciyle yüklü ezgiler ortaya çıkarmışlardır. İnsanların henüz kentten kente gidip gezme olanağı yokken, ortaçağın gezgin ozanları, bir anlamda bugünün medya gücüne sahiptirler. Bu çağın gezgin şarkıcılarının dünyasını zenginleştiren olay, Haçlı Seferleri'yle Avrupa'ya taşınan Arap müziği ve çalgılarının etkisidir (ilyasoğlu, 2008, ss. 24-25). Zamanla tüm Avrupa'ya yayılan gezgin halk ozanları, çeşitli adlarla anılmışlardır. Fransa'da 'troubadour' ve 'trouvère', Almanya'da 'minnesinger', Italya'da 'travatore',
İngiltere'de 'harper', İspanya'da 'trovador', doğuda 'skomorokhi' ve 'barot', kültürümüzde de 'ozan' veya 'âşık' olarak tanınmışlardır. (Selanik, 1996, ss. 46-47).

Takip eden yüzyıllarda gezgin șarkıcılar tarafından sürdürülen bu gelenek sadece müziğe değil, şiire de yeni bir soluk getirmiştir. Şiir, ağır dinsel havasından büyük ölçüde kurtulmuş ve yaşamı çok yönlü biçimde ele almaya başlamıştır (Say, 1997, ss.86-87). Zaman zaman danışmanlık, şifacılık gibi görevler de üstlenebilmiş bu kişiler, şehir şehir, sokak sokak gezmiş, müziklerini icra etmiş, sözlü kültürü aktarmak, gerektiğinde hükümdarı eleştirmek, halkı eğitmek benzeri işlev veya görevlere de sahip olmuşlardır (Malkoç, 2018, s.8). Bir başka deyişle, başlangıçta kilisenin üstünlüğüne boyun eğen bu gelenek özellikle gezgin şarkıcıların etkisiyle zaman içinde şiir ve müzik dolayımıyla yeni bir halk kültürünün filizlenmesine katkıda bulunmuştur. Bu dönüşümün tetikleyici niteliği, sanatın mekânla ilișkisinde yașanan köklü değișimdir. Müzisyenin egemen zümrenin mutlak denetimindeki mekânlardan ayrılması, gezgin sanatçılar olarak halkın arasına karışması ve performanslarını halka ait gündelik mekânlara taşıyabilmesi gösterinin doğasını derinden etkilemiş, ona yeni bir yön ve söylem gücü kazandırmıştır.

XIX. yüzyıla kadar geçen süre içinde sokakta gösteri yapanlara yönelik bakış onların düşkün, aylak, dilenci ve muhatap olunmaması gereken insanlar olduğu yönündedir. Örneğin Ingiltere'de sokak müzisyenleri, Roma döneminden itibaren kent kültürünün bir parçası olmasına rağmen dilenci yerine konularak sürekli baskı altında tutulmuş ve fırsat ortaya çıktığında da cezalandırılmışlardır (Harrison-Pepper, 1990: 23). Bir başka deyişle, sokak sanatçıları egemen değer ölçütlerinin çizdiği çerçevelere sığmadığı, potansiyel bir karşı söylem üreticisi oldukları ölçüde otoritenin kuşkuyla yaklaştığı bir zümre olarak dışlanmış, ötekileştirilmişlerdir.

Figür 2: 1741 'de İngiliz sanatçı William Hogarth tarafından tasvir edilen 'Öfkeli Müzisyen (Enraged Musician)' adlı gravür. Kaynak: http://historyandotherthoughts.blogspot.com/2013/03/thedistressed-poet-and-enraged-musician.html) (Erişim Tarihi 15/4/2019)

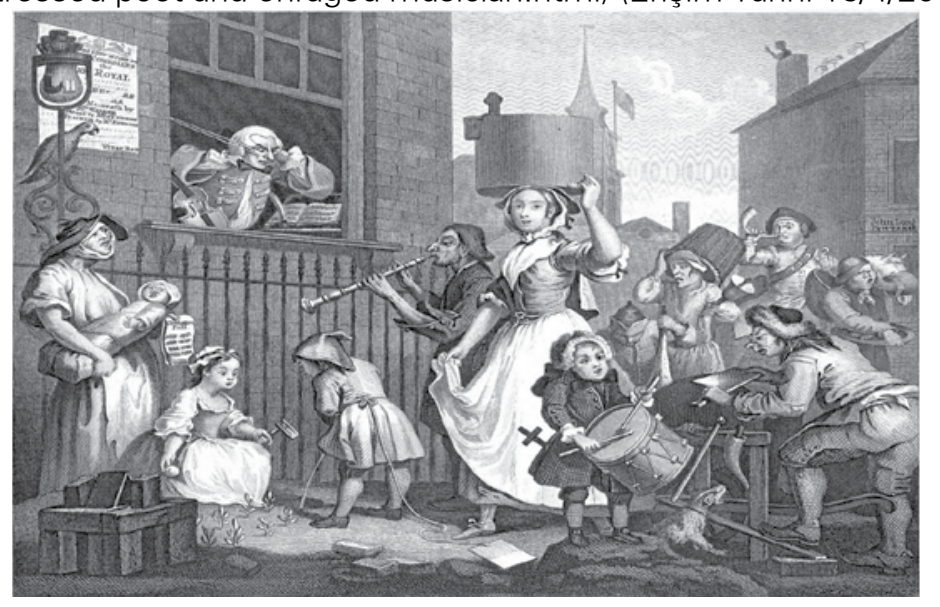


XIX. yüzyılda tüm dünyada, tarihin en büyük nüfus hareketlerinden biri yaşanmıştır. Sanayileşmenin yükselişi, tarımsal krizler, taşımacılıktaki gelişmeler ve fabrika işçiliğine yönelik güçlü ve sürekli talep, İkinci Dünya Savaşı'na kadar geçen yüzyıl boyunca elli beş milyona yakın insanın sanayi şehirlerine göç etmesine ve kentlerdeki nüfusun ölçüsüz yoğunlaşmasına yol açmıştır. Nüfusun hızla arttığı şehirlerin sokakları ise; gezginler, dilenciler, tezgâhtarlar, dolandırıcılar gibi, sahipsiz toplumun geri kalan kesimleri için çeşitli fırsatlar sunmuştur. Sokak müzisyenliği de bu anlamda günlük ihtiyaçları karşılayabilmenin temel yollarından biri haline gelmiştir (Zucchi, 1992, ss.4-5). Bu dönemde kentlerde yaşanan toplumsal dönüşümler sokak müzisyenliğinin işçi sınıfının eğlence ihtiyacını karşılayan bir boș zaman aktivitesi olarak profesyonel bir ișe veya mesleğe dönüșmeye bașlamasının yolunu açmıştır. Örneğin, XIX. yüzyılın ilk yarısında Avrupa'dan göçün artmasına paralel olarak, Amerika'nın New York ve Philadelphia gibi birçok şehrinde sokak müzisyenleri ortaya çıkmıștır. Çoğu İtalyan göçmeni olan bu müzisyenlerin varlığı bu dönemde bazı hoşnutsuzluklar yaratmıştır. Takip eden yıllarda halkı rahatsız ettikleri gerekçesiyle sokak müziği Amerika'nın birçok eyaletinde yasaklanmıştır.

Figür 3: Mulberry Caddesi'nde bir sokak müzisyeni ve polis, 1897.

(Kaynak: http://www.boweryboyshistory.com/2015/02/the-bighistory-of-little-italy.html) (Erişim Tarihi 15/4/2019)

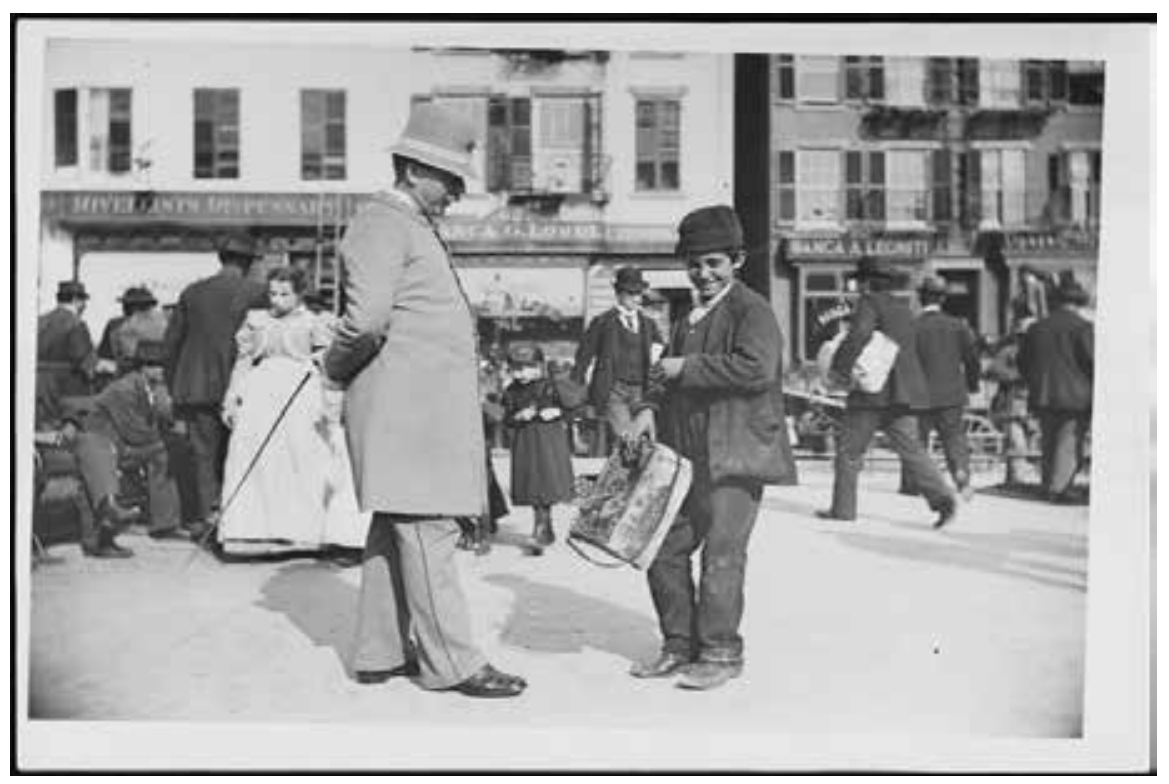

Bu gelişmelerin aksine, aynı dönemde Almanya'da köylerden kentlere göçün sonucunda tavernalarda, kiliselerde, pazarlarda, festivallerde görünür hale gelen sokak müziği halk tarafından memnuniyetle karşılanmış ve bir kültürel zenginlik olarak benimsenmiştir. İlk olarak Güney Bavyera ve Baden eyaletlerinde or- taya çıkan 'sokak koroları' 1800'lü yılların ikinci yarısından itibaren yaygınlaşmaya başlamıştır. James Garratt'a göre, birçok şehirde politik temelleri olan ve ulusal birlik ve siyasi özgürlük temalı şarkılar söyleyen bu topluluklar, aynı zamanda siyasi tartısma için odak noktası mahiyetindedirler. Alman göçmenler tarafından Amerika'ya taşınan bu müzik kültürü Amerikan yaşam tarzını önemli ölçüde etkileyerek on yıllar içerisinde organize, eğlenceli ve canlı bir halk müziği kültürünün gelişimine katkı sunmuștur. Yükselen halk müziği kültürünün en belirgin ișaretleri ise gün geçtikçe çoğalan açık hava konserleri ve müzik festivalleri olmuştur (Wiltse, 2015, ss. 5-8).

XX. yüzyılın başlarında sokak müzisyenleri kent yaşantısının bir parçası olmakla birlikte sanayileşmenin ürettiği meslekler zinciri ve tabakalaşma içinde ayrıksı bir konumda kalmışlardır. XIX. yüzyılın isyan, kaos ve yoksulluk üreten kentleri modern üretim ve yașam tarzının standartlarıyla yeniden düzenlenirken ve daha stabil bir hal alırken, buna uyum sağlayamayan farklı kesimler gibi sokak müzisyenlerinin konumu da muğlaklaşmıştır. Modern kent insanı için işliklerin ve fabrikaların veya servisler sektörünün düzenlenmiş kalıpları dışında kalarak sokakta faaliyete devam eden bu kişiler acıma nesnesine dönüşmüştür. Sokaklarda birkaç kuruş para için çalan müzisyenlerin en düşkün olanlarına tolerans gösterilmiştir (Campbell, 1981, s.11). Yaygın bir deyim olarak kullanılan 'sing for your supper' (akșam yemeği için şarkı söyle) deyimi bu dönemki sokak müziği pratikleri dolayımıyla ortaya çıkmıştır. Sokak müziği için günümüzde kullanılan 'busking' (sokak sanatçılığı) kavramı da ilk olarak bu dönemde kullanılmaya başlanmıştır.

\section{Sokakta Doğan Karşı Sanat: Mücadele ve Müzik}

Markoff (2005, s.9) 1950'li yıllarla birlikte batıda 'konforlu orta sınıf hayat tarzı'na karşı kitlesel siyasal ve toplumsal ayaklanmalarla paralel olarak gelișen dönüşümlerin Amerika'nın savaş sonrası ideallerini reddeden ve siyasal haklar, ekoloji, kadın hakları, savaş karşıtı hareket gibi temalar çerçevesinde bir karşı kültürün olușmasını tetiklediğini belirtir. 'Tarihteki ilk sembolik savaș' olarak da nitelendiriIen 1960'lı yılların gençlik ayaklanması güç ilişkilerinden değil, aksine yaşamdan keyif alma ilişkilerinden kaynaklanmaktadır. Savaş karşıtlığı ve yurttaş hakları gibi politik temalar ön planda olmasına karşın, itirazların asıl hedefini hayata ve sevince düşman olan bir rasyonalizm oluşturmaktadır ve bu rasyonalizm dokunduğu her şeyi ekonomik ve teknokratik amaçlara uygun biçimde şekillendirmektedir. (Gans, 2007, s. 132). Bir önceki kuşağın ve ebeveynlerinin gerçeği olan bu yaşam biçimini değiştirerek bireyin kendi yașamını keyif alınır bir șekle sokabilmesinde gençler için müzik hayati bir rol oynamıştır. Toplumsal protestolarda birçoğu evsiz, parasız ya da işsiz olan genç nüfus sokaklara çıkmaya başlamış ve bu gençler yeni bir amatör sokak müzisyeni neslinin nüvesini oluşturmuşlardır (Campbell, 1981, s. 12).

Sokağın, yapısal ve kurumsal dışlanmaya maruz her türden ötekinin karşı kültürler, hayali cemaatler ve sembolik aidiyetler yoluyla kimlik oluşturmaların- 
da merkezi bir rolü vardır. Gençler açısından vakitlerinin çoğunu geçirdikleri bu kentsel mekânlar, güvenli bir sığınak olduğu kadar, mücadelenin ve çatışmanın yaşandığı ve değişik yerel siyasal kültürlerin yeşerdiği yerlerdir. Bir mücadele alanı olarak sokak ve sanat 1960 'ı yıllarda sanatçılar ve eylemciler için, savaş sonrası dönemde kültürel ve siyasal alanlarda karşılaştıkları kısıtlamaların ötesine geçilmesi noktasında kamusal alanların aktif kullanımıyla ilişkilendirilen önemli bir tema oldu. Oldenburg gibi dönemin önde gelen birçok sanatçısı, sanatın hayata dokunması için müze ve gösteri salonlarının dışına çıkarak kamusal alanlara taşması gerektiğini ileri sürerken birtakım yaratıcı fikirler etrafında birleşiyorlardı (Martin, 2004, s.4). Bu yıllarda kamuya açık yerlerde gerçekleştirilen birçok performans insanların başka hiçbir yerde karşılaşmamış olabilecekleri toplumsal ve politik konuları içermekteydi. Bu hareket çevresinde yeni nesil sokak sanatçıları yer almaktaydı. Örneğin; Janis Joplin, Bob Dylan, Joan Baez ve Jimi Hendrix gibi birçok müzisyen toplumsal muhalefetin ve karşı kültürün yükselmesinde öncü konumundaydılar. Sonuç olarak 1960'lı yıllarda sanat ve siyaset gündelik hayata nüfuz etti. Sokaklardaki kamu performansı ise bu gelişmenin ana forumunu oluşturdu ve kamusal alanı toplumsallaştırmaya dönük bir mekân stratejisi ile bütünleşerek dönemin karşı söylemlerinin ana arterlerinden birisine evirildi.

Figür 4: Phil Ochs, New York'taki Birleşmiş Milletler Binası önünde Vietnam Savașı'nı protesto ederken, 1967.

(Kaynak: https://folkworks.org/reviews/folkworks-film-theaterreviews/40102-phil-ochs-there-but-for-fortune) (Erişim Tarihi 15/4/2019)

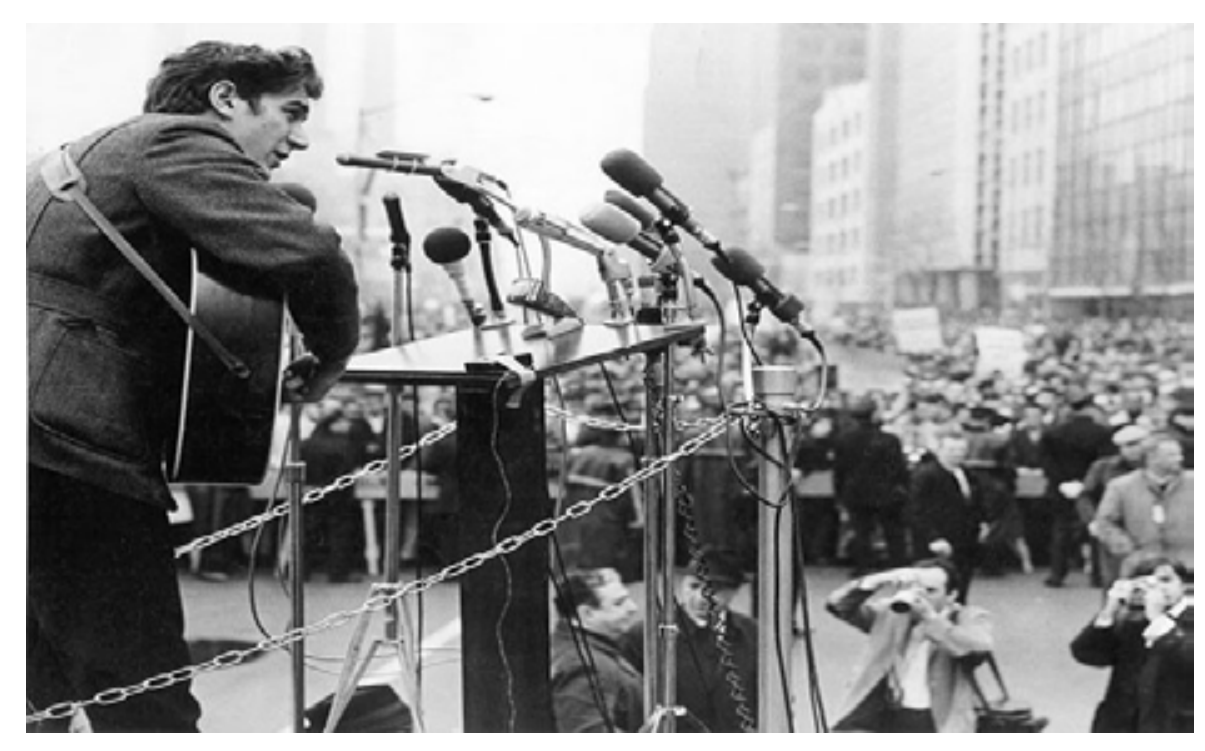

1960'ı yılların ikinci yarısından itibaren daha da görünür hale gelen bu sokak kültürü Birinci Dünya Savaşı'ndan sonra ortaya çıkan bohem kültürünü çağ- rıștırmasının yanı sıra daha önce yașanmış olan avangart yüksek kültürünü de anımsatmaktadır. Ancak burada yeni olan, sokak sanatları ve aktif kamusal performanslar sayesinde bu yüksek kültür biçimlerinin daha aşağı beğeni kültürlerine yayılmış olması, kamusunun geniş̧liği ve desteklediği kültürel yelpazenin içerdiği çeşitliliktir. (Gans, ss. 128-129)

Bu dönemle birlikte sokak sanatı kamusal alanda hakimiyetini arttırmak suretiyle gündelik hayatın rutinine müdahale ederken seyircisiyle dinamik ve deneyimsel bir ilişki kurarak gerçeğe ilişkin fikirleri yeniden yorumlamakta ve biçimlendirmektedir. Bu anlamda sokak müziği de, kamusal alanda eğlence sunmanın dıșında ișlevler edinerek kamuoyuna gündelik yaşamı ve kentsel mekânı bir sanat merceği aracılığıyla görme fırsatı sunmaktadır. Böylece potansiyel olarak protesto aktivitelerinin ve kentsel alanların anlamını ve işlevini yeniden değerlendirmenin sanatsal bir aracısı haline dönüșmüștür (Haedicke, 2013, s. 1). Bu nedenle sokakta serpilip gelişen karşı söylemlerin taşıyıcı ögelerinden olan sokak sanatları, tarih boyunca olduğu gibi egemen güçler tarafından tehdit olarak algılanmıştır. Sokak aktivizmini ve onun söylem taşıyıcılarını bir karșı hegemonya arayıșı olarak tanımlarsak, kamu otoritesinin 60'lı yıllardaki sert tedbirlerinin ve müdahalelerinin nedenini daha iyi kavrayabiliriz.

\section{Günümüz Sokak Müziği}

1970'li yılların sonlarından itibaren egemen güçlerin sokak sanatına ilişkin olumsuz bakış açısının Batı'dan bașlayarak tüm dünyada yavaș yavaș değișmeye başladığı görülmektedir. Her ne kadar yerel makamlar hâlâ sokak performanslarının özellikle yeri konusunda sıkı bir kontrol sağlamaya çalışsalar da, sokak gösterilerine birçok şehirde, özellikle de yoğun tüketimin, nüfus hareketlerinin ve eğlence olanaklarının geniş olduğu metropollerde sıklıkla rastlamak mümkündür. Bu gelişme, yirminci yüzyılda meydana gelen iki büyük dönüşümün sonucu olarak görülebilir. Bunlardan ilki, Birinci Dünya Savaşı'ndan bu yana yaşanan siyasi ve ekonomik değișimler sonucunda sanatın demokratikleşmesi; ikincisi ise iletişim teknolojilerinde yaşanan muazzam dönüşümdür. Fakat, daha da önemlisi canlı, sıra dışı ve renkli gösterilerle şık alışveriş merkezlerinin atmosferinin iyileştirilebileceğinin ve küresel kapitalizmin hızla dönüștürdüğü kent mekânlarının seçici tüketime uygun yeni ve özgün gösteri formlarıyla donatılmasının ekonomik faydalarının anlaşılması sonucu yatırımcılar sokak müziğini yeniden keşfetmiş̧lerdir. Bu amaçla, önceden düzenlenmiş dış mekân performansları aktif olarak teşvik edilmeye ve hatta yerel makamlarca maddi olarak desteklenmeye başlamıştır. Paris'te sokak eğlenceleri için özel olarak tasarlanmış olan 'Pompidou Merkezi' bu anlamda bir dönüm noktasıdır ve diğer şehirler bu örneği takip etmişlerdir. Günümüzde, özellikle Avrupa'da sadece sokak sanatının icra edildiği birçok uluslararası sokak festivali düzlenmektedir. Bazı önyargılar hala devam etse de, sokak sanatına ilişkin talep gün geçtikçe artmaktadır. (Mason, 1992, ss. 8-9). Günümüzün küresel metropollerinin bir çoğunda sokak sanatları etkinliği kentin marka değerinin bir bileşeni olarak pazarlanmakta ve kentteki potansiyel tüketiciye 
meta olarak sunulmaktadır. Egemen güçlerin sokak sanatı üzerinde kurduğu bu tahakküm iki aşamalı olarak gerçekleşmektedir. Kamu otoritesi sokak etkinlikleri ve aktivist sanatsal eylemler için halk tarafından geleneksel olarak kullanılagelen veya özerkleştirilmiş ya da işgal edilmiş, yahut da önceki işlevlerini kaybetmiş (işlikler, fabrikalar, antrepolar, askeri tesisler, vb.) kamusal mekânları önce kendi kontrolüne geçirmekte, ardından da bu mekânları sermayeye devrederek şirketler üzerinden mutenalaştırma yoluna gitmektedir. Illk bakışta bu mekânların çoğunun hâlâ bağımsız sanatsal aktiviteler için kullanıldığı düşünülebilirse de, kamusal alanlara yayılan sokak gösterilerinin tüketim ve eğlence alışkanlıklarının önemli bir parçası olarak sponsorluklarla ve reklamlarla desteklenerek sömürgeleştirildiği (ehlileştirildiği) unutulmamalıdır.

Figür 5: Pompidou Merkezi Bölgesi'ndeki Sokak Müzisyenleri, Paris, 2010

(Kaynak:https://commons.wikimedia.org/wiki/File:Guitar_busking_ outside_the_Pompidou_centre,_Paris,_France.jpg) (Erişim Tarihi: 15/4/2019)

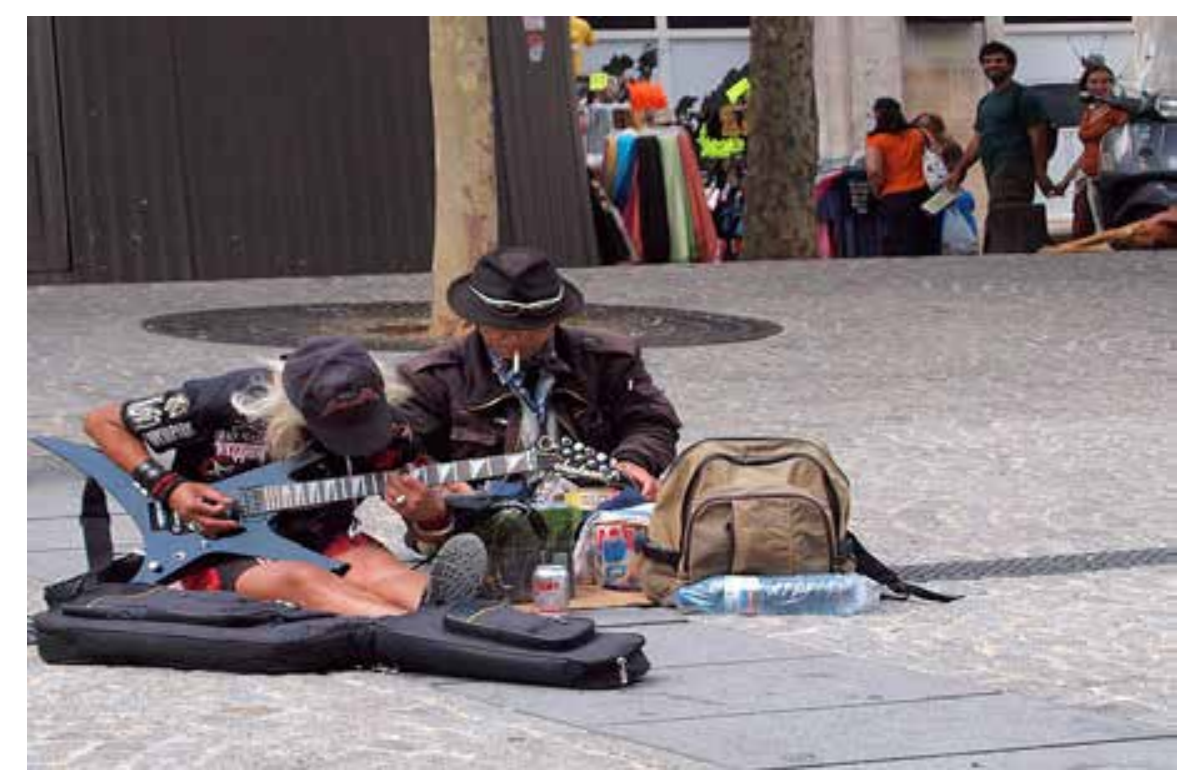

Bu bağlamda, Baudrillard'ın 'hipergerçeklik' kavramı önemli bir açılım sağlamaktadır. Bu kavramın temelinde, günümüz medya doyumlu kültürünün özgün gerçeklik temsillerinin yerini alan gerçek dünya simülasyonları yarattığı düşüncesi yatar. Bir fantezinin ürünü olan 'Disneyland' Baudrillard'a göre 'hipergerçek ve simülasyon düzleminde, bizi geri kalan her şeyin gerçek olduğuna inandırmak' gibi başka bir işleve daha sahiptir (Laughey, 2010, ss.101-102). Günümüzün kentsel yerler dokusuna işlenen kamusal fantezi mekânları da benzer işlevlerle donatılmış gibidir. Seçici tüketim mekanlarından farklı olarak, Berlin'deki Tachales, Budapeş- tede'ki Simplakert veya Ljubliana'daki Metelkova gibi sıra dışı mekanlar da tıpkı Disneyland'da olduğu gibi yoğun bir fantazmagori üretirler. Disneyland'ı ziyaret eden turistler artık var olmayan ama sürekli özlem duyulan bir geçmişin anılarını metalaștıran bu mekânı yalnızca tüketici olarak deneyimleyebilmektedirler. Geçmişin parlak aktivizm ve isyan günlerinin düşleriyle dolu kamusal mekânların evrimi de Disneyland hipergerçekliğini hatırlatmaktadır. İnsanları bu mekânlara çeken şey, memnun olmadıkları dünyayı dönüștürmek yerine onun kabul edilebilir bir versiyonu olarak üretilmiş bir fanteziyi satın alabilme fırsatının kendilerine sunulmuş olmasıdır. Böylelikle, bu mekânlarda vuku bulan faaliyetler kamusal alanı kucaklayan etkin ve anlamlı sokak gösterisinin yerini alarak onu gerçekte var olmayan yeni bir bünyeye taşımaktadır.

Kültür endüstrisi eninde sonunda direnişi tüketim ve kar amaçlı olarak pazarlamayı başarır. Hebdige'in (2004, s. 96) ifade ettiği gibi, 'kültürel tarzlar sembolik mücadeleler vererek başlayabilir, ancak bunlar yeni değerler ve tarzlar oluşturarak yeni ürünler, sanayiler yaratarak ya da eskileri ile tekrar canlandırılarak sona ererler.' Ted Polhemus'un 'Streetstyle' adlı kitabı (özellikle de 'From Sidewalk to Catwalk' alt başlığı), günümüz gençlik kültürünün yaşadığı değişimi gözler önünde serecek nitelikte olması açısından önemlidir. Polhemus bu bağlamda, modanın sokakta, gösterilerde, festivallerde, diskolarda, revülerde nasıl oluştuğunu ve bunun ticari olarak moda fikrine nasıl dönüștüğünü dile getirmektedir (Barnard, 2002, s. 46-244). Kültürel bağlamda gençlere sunulan en önemli seçenek müziktir. Müziğin tüketimi, gençlerin kendini diğer toplum üyelerinden ayırarak kimliğini geliștirdiği ve kültürel olarak kendini yenilediği araçlardan biridir. Riesman'a (2000, s. 8-10) göre bir topluluğun gerçek ya da hayali olmasından ziyade müziğin bir topluluk hissi yaratıyor olması durumu önemlidir. Bu, tüketim eylemi içerisinde olușturulmuş bir topluluktur ve dinleyici müziği dinlerken yanında kimse olmasa bile tükettiği müzik bağlamında aralarında hayali bir bağ kurulmuştur.

Gençlerin kendilerine özgü gereksinimlerinin ve tüketim alışkanlıklarının olduğunun keşfi, sanatsal ve sosyal-politik beklentilere cevap veren müzikal ve kültürel bir hareket haline dönüşerek kabul görmeye başlayan sokak müziğinin de zaman içinde 'temiz ve zararsız' alternatif semboller yaratılarak herkes tarafından dinlenebilecek yeni bir biçime sokulması sonucunu beraberinde getirmiştir. (Wicke, 2006, ss. 256-259). Bu noktadan itibaren çelişkiliymiş gibi görünen bir şekilde sokak müziğinin de, muhalif olma özelliklerini yitirerek çeşitli mecralar aracılığıyla karşısında oldukları sistemin bir parçası haline gelmeye başladığını söylemek mümkündür.

\section{Sonuç}

Geleneksel gösteriler tarih boyunca egemenlerin uhdesinde gelişmiş ve iktidar sahiplerinin kültürel ve toplumsal referansları doğrultusunda biçimlenmiştir. Halk kesimlerini gösterilerin seyreyleyeni halinde hareketsiz tutan büyük gösteriler mecra olarak kimi zaman kamusal alanları kullansa da otoritenin söylem 
gücüyle donatılmıș anlatılar genellikle ayrıcalıklı mekânlarda icra edilmiștir. Sokak bu bağlamda, kamusal alanın devlet gücü veya otorite tarafından denetlenmeyen parçasını, gücün bakışlarından azade tutulan bir zamansal mekânsal boyutu temsil eder. Saraylar, tapınaklar, stadyumlar veya amfi tiyatrolar egemenlerin mekânıyken, sokaklar halka aittir. Sokak sanatları ve müziği bu nedenle tarih boyunca folklorik anlatılar olarak gelişmiştir. Fakat bundan da önemlisi, özgün bir anlatı olarak egemen güçlerin biçimlendirdiği söylem karşısında halkın duygu ve düşüncelerini, kendine özgü yanıtlarını içinde barındıran özgün bir gösteri formu olmasıdır.

Tarihsel perspektifte ele alacak olursak, sokak sanatının toplumları etkileyebilme, örgütleyebilme, hareketlendirebilme ve böylece değiştirebilme gücüne sahip olduğu söylenebilir. Fakat sokak sanatının modern kültürümüzdeki evrimsel yolculuğu, içinde biçimlendiği tarihsellikten farklı yerlere doğru savrulmasıyla sonuçlanmıştır. Sokak sanatları ve müziği modern gösteri toplumunun temelini oluşturan tüketim ve eğlence kültürünün bünyesine taşındığı ölçüde işlev ve biçim değiştirmektedir. Bu bağlamda özgün bir ifade biçimi olarak sokak müziğinin çerçevesi orta sınıf değerleri etrafında oluşmakta, hegemonik yapıların yeniden üretilmesinde git gide daha fazla anahtar rol oynamaktadır. Bu bağlamda, özellikle sokak gösterileri, farklııklarıyla bu çok kültürlü yapının zengin ve renkli dokusuna katkı sağlasalar da, esasen orta sınıfın değerleri etrafında şekillenen popüler kültürün bir ögesine dönüșmenin ötesine gidememektedirler. Günümüzde dünya çapında tanınmış birçok sanatçının kariyerine sokak müzisyeni olarak başlamış olması bu tespiti doğrular niteliktedir.

Gün geçtikçe, ana akım kültürün içine dâhil edilen sokak müziği artık sadece bir boş zaman pratiği olarak sunulmakta, böylece eğlenceli bir tüketim nesnesi olarak gösteriler evreninin içindeki yerini almaktadır. Sokak müziğinin muhalif tavrı ve yıkıcı gücü tüketiciye sunulan reklâm ve paketleme içinde kaybolmakta, ticari oluşumları kapsayan bir yapının ihtiyacını karşılayacak modaların oluşturulması noktasında önem kazanmaktadır. 'Öteki', kültür endüstrileri tarafından evcilleştirilerek devamlı olarak merkez kültüre katılmakta ve bir 'çok kültürlülük' iklimi olarak sunulan toplumsalın kimlik kazanma dinamiklerine ve tarz arayışlarına bağımlı hale gelmektedir. Yeni hâkim kültürel ortamda, farklıık bir tehdit oluşturmanın ötesinde değişim değeri üretme potansiyeli çerçevesinde kurgulanmaktadır. Sokak müziği de, kültürel hegemonyanın sürekli yeniden üretildiği kültür endüstrilerinin çarklarından birisine dönüşmektedir.

\section{Kaynakça}

Akın, F. (2005), Crossing The Bridge: The Sound of İstanbul (Film).

Barnard, M. (2002) Sanat, Tasarım ve Görsel Kültür, (G. Korkmaz, Çev.). Ankara: Ütopya Yayınevi.

Bradford D. M. (2004), The Theater is in the Street: Politics and Performance in Sixties America, Boston: University of Massachusetts Press.
Campbell, J. P. (1981), Passing the Hat: Street Performers in America, New York: Delacorte Press.

Gans, H. J. (2007), Popüler Kültür ve Yüksek Kültür, (E. Onaran İncioğlu, Çev.). İstanbul: Yapı Kredi Yayınları.

Haedicke, S. C. (2013), Contemporary Street Arts in Europe Aesthetics and Politics, London: Palgrave MacMillan.

Harrison-Pepper, S. (1990), Drawing a Circle in the Square: Street Performing in New York's Washington Square Park, London: University Press of Missisippi.

Hebdige, D. (2004), Altkültür: Tarzın Anlamı, İstanbul: Babil Yayınları.

Hoffer C. (2012), Music Listening Today, Boston: Schirmer Cengage Learning.

İlyasoğlu E. (2008), Zaman İçinde Müzik, Ankara:Remzi Kitabevi.

Laughey, D. (2010), Medya Çalışmaları: Teoriler ve Yaklaşımlar, (A.Toprak, Çev.) Istanbul: Kalkedon Yayınları.

Malkoç I.B. (2018), Sokak Müzisyenlerinin Müzik Yapma Amaçları ve Mekân Seçimleri Arasındaki Illişki: İstanbul, Kadıköy Örneği, Online Journal of Music Sciences, 3 (1), 06-31.

Markoff, J. (2005), What the Dormouse Said: How the Sixties Counterculture Shaped the Personal Computer Industry, London: Penguin Books.

Mason, B. (1992), Street Theatre and Other Outdoor Performance, London and New York: Routledge.

Riesman, D. (2000), "Listening to Popular Music", Frith,A. Goodwin (eds), On Record: Rock, Pop, and The Written Word, New York, Pantheon Books, 4-11.

Say A. (1997), Müzik Tarihi, Ankara: Müzik Ansiklopedisi Yayınları.

Selanik C. (1996), Müzik Sanatının Tarihsel Serüveni, Ankara: Doruk Yayımcılık.

Wicke, P. (2006), Mozart'tan Madonna'ya: Popüler Müziğin Bir Kültür Tarihi, İstanbul: Yapı Kredi Yayınları.

Wiltse, J. (2015), Cities are Alive with the Sound of Music: Saengerfest and the Transformation of Urban Public Music in Nineteenth-Century America, American Nineteenth Century History, Routledge, 16(3), 269-296.

Zucchi, J. E. (1992), The Little Slaves of the Harp, London: McGill-Queen's University Press.

Figür 1. http://www.medievalists.net/2012/02/troubadours-and-their-heritage-inthe-edges-of-europe-singing-and-rapping-experiences-of-being-in-a-minority-insouthern-france-and-in-samiland/ (Erişim Tarihi 15/4/2019)

Figür 2. http://historyandotherthoughts.blogspot.com/2013/03/the-distressed-poet-and-enraged-musician.html (Erişim Tarihi 15/4/2019) 
Figür 3. http://www.boweryboyshistory.com/2015/02/the-big-history-of-little-italy.html (Erişim Tarihi 15/4/2019)

Figür 4. https://folkworks.org/reviews/folkworks-film-theater-reviews/40102-philochs-there-but-for-fortune (Erişim Tarihi 15/4/2019)

Figür 5. https://commons.wikimedia.org/wiki/File:Guitar_busking_outside_the_ Pompidou_centre,_Paris,_France.jpg (Erişim Tarihi 15/4/2019) 